\title{
Reducing Substrate Moisture Content during Greenhouse Production of Poinsettia Improves Postproduction Quality and Economic Value
}

\author{
Yanjun Guo', Terri Starman, and Charles Hall \\ Department of Horticultural Sciences, Texas A\&M University, 2133 TAMU, \\ College Station, TX 77843
}

Additional index words. water stress, water, postharvest, postproduction longevity

\begin{abstract}
The objective was to determine the effect of substrate moisture content (SMC) during poinsettia (Euphorbia pulcherrima) greenhouse production on plant quality, postproduction longevity, and economic value. Two experiments were conducted, one in 2016 with 'Freedom Red' and the other in 2017 with 'Christmas Eve Red'. Treatments included two SMC levels $(20 \%$ or $40 \%)$ applied in four timing of application combinations. Total production (TP) time was 14 (2016) or 12 (2017) weeks in which vegetative production (VP) occurred from week 33 (2016) or 35 (2017) to week 39 and reproductive production (RP) continued from week 40 to 47 . The four timing of application treatments were $40 / 40=\mathrm{TP}$ at $40 \% \mathrm{SMC} ; 20 / 40=\mathrm{VP}$ at $20 \%+\mathrm{RP}$ at $40 \% ; 40 / 20=V P$ at $40 \%+R P$ at $20 \% ; 20 / 20=$ TP at $20 \%$ SMC. After simulated shipping in the dark, plants were evaluated in a simulated retail environment with two packaging treatments: no sleeve covering or plastic perforated plant sleeves covering container and plant. At the end of greenhouse production, plants grown in $20 \%$ SMC during RP (20/20 and 40/20) had shorter bract internode length, stem length, and smaller growth index (GI), decreased shoot and root dry weight (DW), and bract and leaf surface area compared with those in $40 \%$ SMC during RP (40/40 and 20/40). Photosynthetic rate was higher when plants were watered at $40 \%$ SMC regardless of production stage compared with those in $20 \%$ SMC. Leaf thickness, petiole thickness, total bract and leaf number were unaffected by SMC treatments. Plants in $20 \%$ SMC during RP (20/20 or 40/20) had earlier bract coloring despite days to anthesis being the same for all SMC treatments. Compared with $40 / 40,40 / 20$, and $20 / 20$ could save $44.2 \%$ or $43.6 \%$, respectively, irrigation and fertilizer usage, and $39.1 \%$ and $47.8 \%$, respectively, labor time. During postharvest, ethylene concentration was unaffected by packaging method. Sleeved plants, regardless of SMC treatment, received lower light intensity in the middle of the plant canopy, causing plants to have lower total leaf number due to abscission and SPAD reading at the end of postproduction. The 40/40 treatment abscised more bracts during five weeks (in 2016) of postproduction and with no sleeve had higher number of bracts with bract edge burn (BEB). In summary, reducing SMC to $20 \%$ during TP or RP reduced water usage during production and produced more compact plants with increased postproduction quality.
\end{abstract}

Potted poinsettias are one of the most important greenhouse ornamental crops in the United States, with wholesale value of $\$ 140$ million in the top 15 states. The potted poinsettia was ranked number two among potted plants for its economic value and ranked number one for total amount of potted plants sold (32 million pots) (USDA, 2016).

The greenhouse production process of poinsettias could have an influence on its economic value, especially when the poinsettia production margin is low due to competitive pricing (Barnes et al., 2014). One strategy for increasing profits is to reduce production inputs, such as irrigation water, fertilizer, plant growth regulators (PGR), overhead (i.e., bench space), and labor.

Received for publication 13 Aug. 2018. Accepted for publication 11 Sept. 2018.

'Corresponding author. E-mail: cguo@tamu.edu. production. The timing of application of water deficit affected poinsettia (Euphorbia pulcherrima 'Classic Red') stem elongation depending on growth and development stage (Alem et al., 2015a, 2015b). Periods of 20\% SMC application were used for height control when plant height exceeded the target height using graphical tracking. Applied water deficit during the vegetative growth stage of poinsettia reduced transpiration rate $(\mathrm{E})$ and net photosynthetic rate $\left(\mathrm{P}_{\mathrm{n}}\right)$, but not during the flowering and bract coloring development stage (Nowak, 2002).

Grower profits are increased when overhead and labor costs and postharvest shrinkage are reduced. Poinsettia postproduction disorders include stem breakage, bract fading, leaf yellowing, bract edge burn (BEB, also known as bract necrosis), and bract bruising (Ranch, 2012). Frequent irrigation with fertilization throughout the production cycle increased botrytis infection, weak lateral stems, and late stretch, resulting in postproduction stem breakage and BEB (Barrett et al., 1995; Ecke et al., 2004; Islam and Joyce, 2015; Nell and Barrett, 1986). Postproduction environment temperature, humidity, and irregular irrigation were believed to cause leaf yellowing and leaf drop (Islam and Joyce, 2015). Meanwhile, despite the nearly four decades of research, the effect of production water usage on poinsettia postproduction longevity was still unclear (Islam and Joyce, 2015; Nell et al., 1995).

The objectives of the current study were to a) ascertain the effects of lowering SMC to conserve water during production on plant quality; b) determine if plants produced at lower SMC will acclimate to suboptimum irrigation conditions during shelf life; c) analyze the economic dimensions of traditional well-irrigated vs. water-conserving alternative irrigation methods considering production inputs and reduction in shrinkage through the market channels; and d) quantify plant quality during shelf life in a simulated retail environment.

\section{Material and Methods}

Applying liquid fertilizer with each irrigation is a common practice for poinsettia production (Ecke et al., 2004). Traditionally, water deficit was considered detrimental during greenhouse poinsettia production because wilting between watering decreased plant quality by causing lower leaf drop. Additionally, using water deficit as a plant height control was reported ineffective (Dole and Wilkins, 1999; Schuch et al., 1996). However, more recent studies reported that a constant $20 \%$ substrate moisture content (SMC) could be used as a replacement for PGR (daminozide) applications to produce more compact plants (Alem et al., 2015a). Plant growth regulator application may reduce bract size in poinsettia, which is detrimental to plant quality (Meijón et al., 2009).

Poinsettia is an obligate short day/long night photoperiodic plant and therefore has distinct vegetative growth and reproductive development stages during greenhouse
Plant materials and growing conditions. In 2016, 240 poinsettia (Euphorbia pulcherrima 'Freedom Red') well-rooted cuttings with an initial growth index [GI = plant height $/ 2+$ (plant width $1+$ plant width2)/4] of $39.5 \mathrm{~cm}$ were obtained from a local nursery, graded for uniformity, and transplanted on week 33 (17 Aug.) into $1.67 \mathrm{~L}$ azalea containers (HC Companies, Inc., Middlefield, $\mathrm{OH}$ ) with commercial peat based soilless root substrate $(85 \%$ Canadian sphagnum peatmoss and $15 \%$ perlite; BM 6, Berger, Saint-Modeste, Canada). On 1 Sept. 2017 (week 35), 192 poinsettia 'Christmas Eve Red' well-rooted cuttings with an initial GI of $13.1 \mathrm{~cm}$ were received through Dümmen Orange (Columbus, $\mathrm{OH}$ ), graded for uniformity and transplanted to $1.25 \mathrm{~L}$ azalea containers (HC Companies, Inc.) with the same substrate. All plants were pinched two weeks after transplanting, leaving seven 
nodes, according to protocols for commercial poinsettia production (Ecke et al., 2004).

During greenhouse production, plants were grown in a glass wall and polycarbonate roof greenhouse in College Station, TX. Plants had $14 \mathrm{~d}$ for root establishment before initiation of SMC treatments. During the greenhouse production period, a watersoluble fertilizer $(20 \mathrm{~N}-4.4 \mathrm{P}-16.6 \mathrm{~K}$ Peters 20-10-20; Scotts Miracle-Gro Company, Marysville, $\mathrm{OH}$ ), was applied with each irrigation, with a nitrogen concentration of $200 \mathrm{mg} \cdot \mathrm{L}^{-1}$ and reverse osmosis water (RO). Plants were treated with an etridiazole and thiophanate-methyl (Banrot; Everris NA Inc., Dublin, $\mathrm{OH}$ ) root substrate drench monthly to prevent root rot. Imidacloprid (Marathon; OHP, Inc., Bluffton, SC) was applied early in production to target whiteflies. No plant growth regulators were used.

The average temperature in the greenhouse during the production stage of 'Freedom Red' (2016) was $25.8{ }^{\circ} \mathrm{C}$ day $/ 23.3{ }^{\circ} \mathrm{C}$ night. Average DLI was $13.8 \mathrm{~mol} \cdot \mathrm{m}^{-2} \cdot \mathrm{d}^{-1}$ and relative humidity was $70.3 \%$. During the 2017 'Christmas Eve Red' production stage the average temperature, DLI, and relative humidity were $25.4{ }^{\circ} \mathrm{C}$ day/ $22.7{ }^{\circ} \mathrm{C}$ night, $16.2 \mathrm{~mol} \cdot \mathrm{m}^{-2} \cdot \mathrm{d}^{-1}$, and $63.8 \%$, respectively. Environmental data were measured by WatchDogs 450 and LightScout quantum light sensors (Spectrum Technologies Inc., Aurora, IL). Root substrate EC and pH were measured weekly after irrigation event using the Pour-Through method (Cavins et al., 2000), and were not different between SMC treatments within cultivars. The $\mathrm{EC}$ and $\mathrm{pH}$ were $2.1 \mathrm{~ms} \cdot \mathrm{m}^{-1}$ and 5.7 for 'Freedom Red' and $2.6 \mathrm{~ms} \cdot \mathrm{m}^{-1}$ and 6.2 for 'Christmas Eve Red'.

Substrate moisture content treatments. The experiments consisted of two SMC levels, $20 \%$ and $40 \%$, applied in four timing applications. Total production (TP) took place weeks 33-47 (2016) or 35-47 (2017); vegetative production (VP) took place weeks 33-39 (2016) and weeks 35-39 (2017); and reproductive production (RP) weeks $40-47$ (2016 and 2017). Four timing of application treatments included 1) $40 / 40=\mathrm{TP}$ at $40 \%$ SMC; 2) $20 / 40=\mathrm{VP}$ at $20 \%+\mathrm{RP}$ at $40 \%$; 3 ) $40 / 20=\mathrm{VP}$ at $40 \%+\mathrm{RP}$ at $20 \%$; 4) $20 / 20=$ $\mathrm{TP}$ at $20 \%$ SMC. Natural short days began at week 40 and that was when SMC treatments were interchanged for treatment two and three. SMC was defined as $V_{\mathrm{W}} / \mathrm{V}_{\mathrm{T}}\left(\mathrm{V}_{\mathrm{W}}\right.$ is the volume of water; $\mathrm{V}_{\mathrm{T}}$ is the total volume of substrate, water, and air space). The 40/40 was considered to be a traditional wellirrigated method, which allows the substrate to dry down to $40 \%$ SMC before being handwatered to container capacity (CC, 65.5\% $\mathrm{SMC}$ ), whereas the other three SMC treatments, 20/40, 40/20, and 20/20, were alternative water-conserving irrigation methods, which during VP and/or RP production allows substrate to dry down to $20 \%$ SMC before being hand-watered to $\mathrm{CC}$. Each irrigation event was determined based on the average of readings of SMC level within the same SMC treatment. Substrate moisture contents were monitored by WatchDog 1000 series Micro Stations and SM 100 WaterScout soil moisture sensors (Spectrum Technologies, Inc.). There was one sensor per block per irrigation treatment. The greenhouse production stage used the same irrigation sensor system described in a previous study (Guo et al., 2018).

Sensor calibration. Soil moisture sensors were calibrated before the experiment by filling five 1-L plastic beakers with 1-L volume of oven dried root substrate. Substrate density was unified by tapping dry substrate-filled plastic beakers five times from a uniform height $\approx 3$ to $6 \mathrm{~cm}$ above a sturdy table (Fonteno et al., 1995). This was followed by emptying each beaker into one of five polyethylene plastic bags (Ziploc; S.C. Johnson \& Son, Inc., Racine, WI), and $100,200,300,400$, or $500 \mathrm{ml}$ of water were poured into one of the five bags. Next, root substrates were mixed with the water thoroughly and allowed to incubate for $24 \mathrm{~h}$. Each substrate's dry weight (DW) and wet weight (WW) was measured and recorded before repacking into the same plastic beaker as previously. Three sensor readings were taken at three different locations in the beaker, avoiding taking readings too close to the edge according to WaterScout SM 100 Soil Moisture Sensor product manuals. SMC calculation was
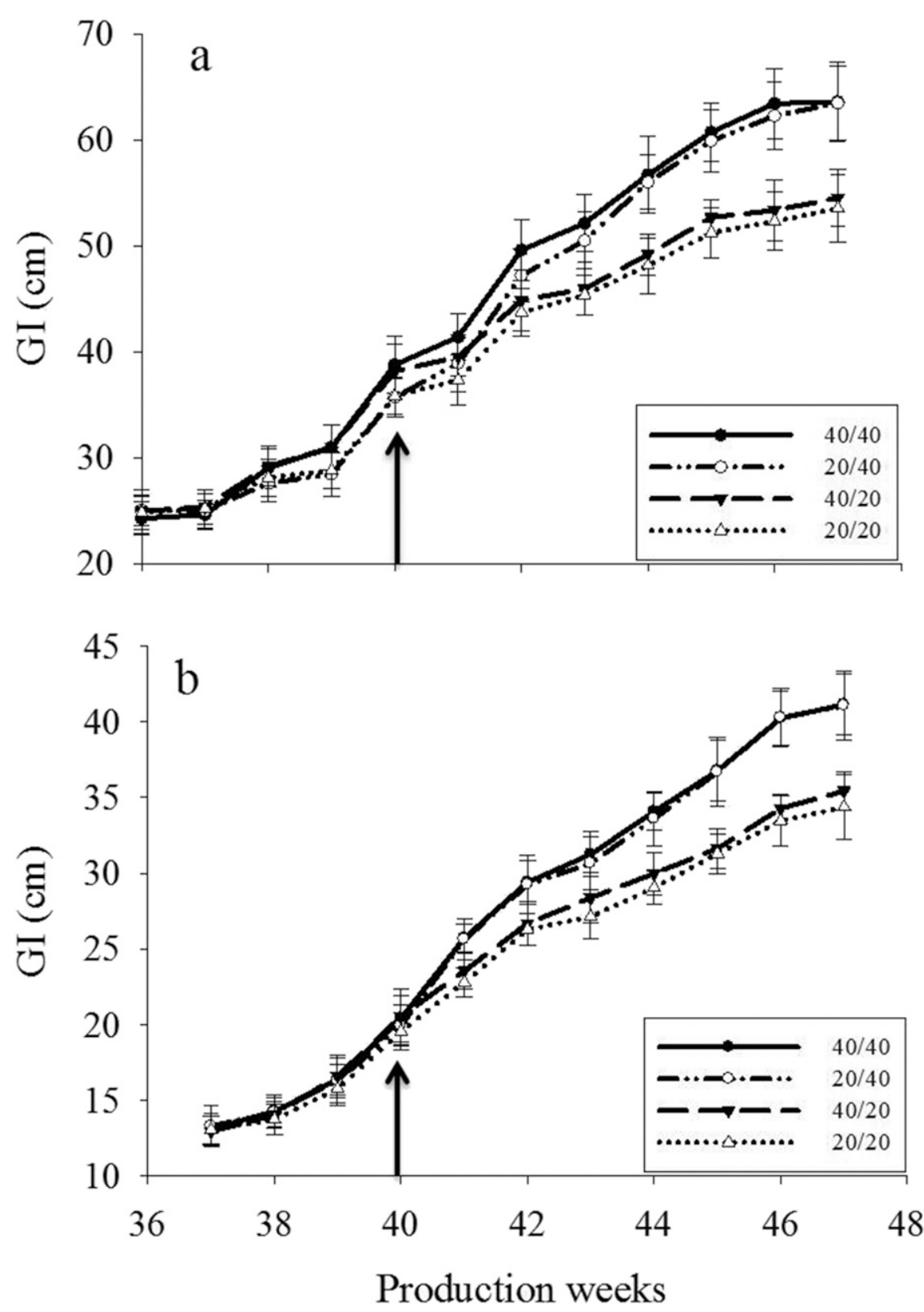

Fig. 1. Effects of four SMC treatments (40/40, 40/20, 20/40, and 20/20\% SMC) on weekly growth index [GI $=$ plant height $/ 2+($ plant width $1+$ plant width 2$) / 4]$. from production week 36 to production week 47 of 'Freedom Red' in 2016 experiment (A), and from production week 37 to production week 47 of 'Christmas Eve Red' in 2017 experiment (B). The arrow denotes week 40 as the start of short day photoperiod and when SMC treatments were interchanged. 
$\mathrm{SMC}=(\mathrm{WW}-\mathrm{DW}) \times 100 \% / 1000$ (Cai et al. 2012, 2014).

Post production treatments. During simulated shipping and shelf life in both experiments, plants were treated with one of two packaging methods (PM): either no sleeve (NS) or sleeved (PS) with plant sleeves that were half nonwoven cloth-like polypropylene fiber and half micropunched clear polypropylene (Super Breather; A-ROO Company of Texas LLC, Seguin, TX). In week 47 (27 Nov. 2016), 'Freedom Red' poinsettias were deemed marketable with one open cyathia and red bracts covering $88 \%$ of the shoot canopy before simulated shipping. Simulated shipping consisted of hand-watering plants with reverse osmosis water to container capacity before applying sleeve treatments and moving by cart into a dark laboratory for $48 \mathrm{~h}$ at $19.3{ }^{\circ} \mathrm{C}$ and $55.5 \%$ relative humidity. After shipping, plants were held in the laboratory environment with $24 / 7$ interior incandescent + fluofor simulated shelf life, during which plants were watered with RO water only when wilting began to occur. During postproduction, the average temperature, daily light integral (DLI) and relative humidity were $20.2{ }^{\circ} \mathrm{C}, 1.3 \mathrm{~mol} \cdot \mathrm{m}^{-2} \cdot \mathrm{d}^{-1}$, and $39.2 \%$, respectively.

In 2017, with 'Christmas Eve Red', an additional factor of harvest time was added during postharvest to determine if harvesting before or after cyathium-shed pollen would affect shelf life. Therefore, the three factors during postproduction were 1) SMC; 2) PM; and 3) harvest time (HT). HT consisted of either early harvest shipped week 46, and postproduction week 47 to 48 , or late harvest shipped week 47 , and postproduction week 48 to 49 . For early harvest, plants had red bracts covering $80 \%$ of the plant canopy and no open cyathia or pollen shed; whereas for late harvest, plants had red bracts covering $90 \%$ of the plant canopy and one open cyathia with pollen shed before simulated shipping. The simulated shipping process was the same as in 2016 with the exceptions of a reduced dark period of $12 \mathrm{~h}$ at $21.8{ }^{\circ} \mathrm{C}$ and $42.4 \%$ relative humidity and a simulated shelf life of two weeks with average temperature, DLI, and relative humidity of $21.7^{\circ} \mathrm{C}, 1.6 \mathrm{~mol} \cdot \mathrm{m}^{-2} \cdot \mathrm{d}^{-1}$, and $42.5 \%$, respectively. During postproduction in 2017, plants were irrigated with $300 \mathrm{ml}$ plain RO water when they showed signs of wilting.

Physiological parameters. Instantaneous leaf gas exchange parameters [net carbon assimilation rate $\left(\mathrm{P}_{\mathrm{n}}\right)$, stomatal conductance $\left(g_{\mathrm{S}}\right)$, and transpiration rate $\left.(\mathrm{E})\right]$ were measured weekly during production on the third fully unfolded young leaf between 1000 and $1200 \mathrm{HR}$, using a portable photosynthesis system (LI-6400XT; LI-COR Inc., Lincoln, $\mathrm{NE}$ ) with the cuvette conditions set at $25^{\circ} \mathrm{C}$, $1200 \mu \mathrm{mol} \cdot \mathrm{m}^{-1} \cdot \mathrm{s}^{-1}$, and $400 \mu \mathrm{mol} \mathrm{CO}_{2}$. Weekly measurements from week 38 to 45 included relative greenness of leaves (SPAD) measured with a chlorophyll meter (SPAD502; Minolta Camera Co., Osaka, Japan), and rescent lighting for five weeks (week 47-52)

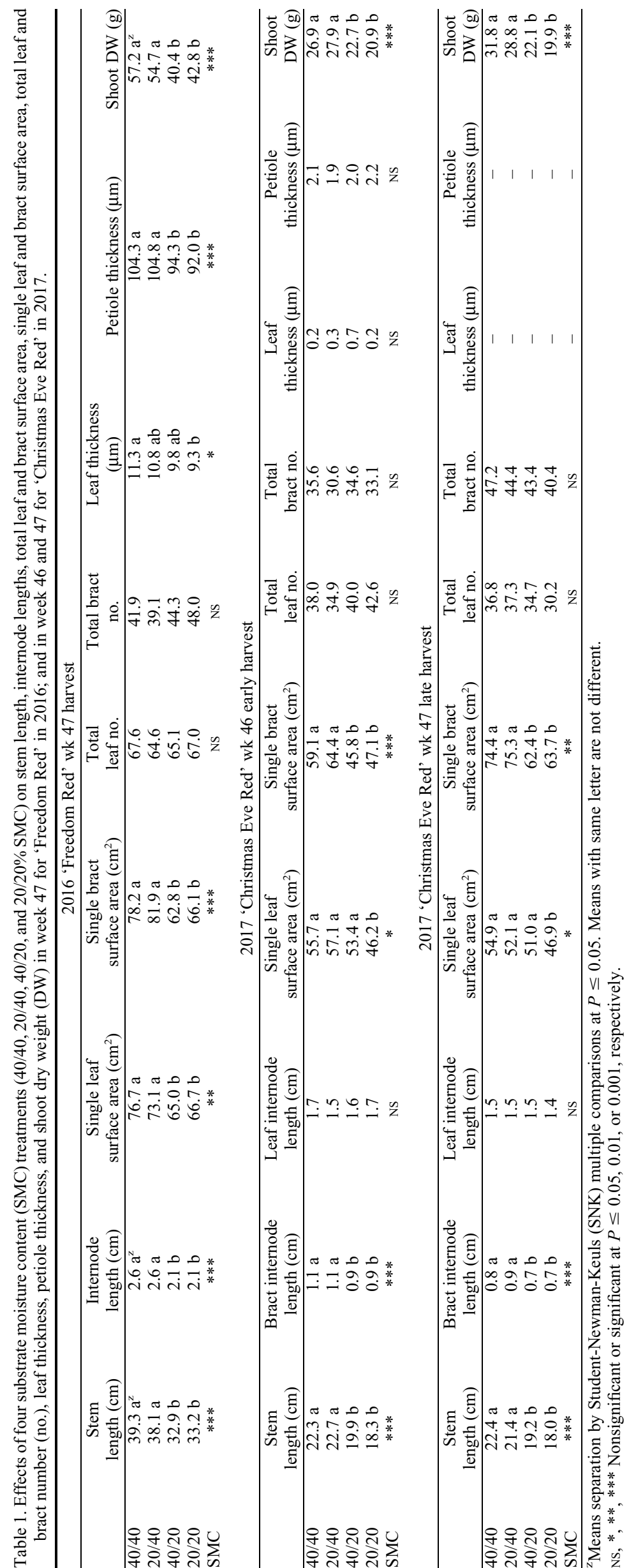


predawn and midday leaf water potential with a pressure bomb (Soil Moisture Equipment Corp., Santa Barbara, CA). SPAD readings ranged from 0 to 100 by measuring the light transmission at wavelengths of 650 and $940 \mathrm{~nm}$ (Markwell et al., 1995).

Production plant quality parameters. Plant growth index (GI) was recorded weekly. At the end of greenhouse production, for both 'Freedom Red' and 'Christmas Eve Red', half of the plants per treatment per block were destructively harvested to collect total bract and leaf number, bract and leaf surface area, stem length, node number, internode length, and shoot dry weight. In 2017, leaf thickness between two major leaf veins and petiole diameter were measured on a young fully expanded leaf with a digital caliper during early HT, and open and closed cyathia number per lateral branch were counted during late HT. The other half of the plants were used for the postharvest stage of the study.

To quantify the bract coloring percentage (the percentage of the plant canopy that was covered by red bracts) during production week 44 to 46 , photos of poinsettia shoots were taken from above. Photoshop CS 6 (Adobe Systems Inc., San Jose, CA) was used to quantify the red area (bracts) and green area (leaves), and the coloring percentage was calculated as [red area / (red area + green area) $] \times 100 \%$. At the end of greenhouse production root ball pictures were taken from the bottom of the root ball and both sides of the root ball. Root ball coverage percentage was quantified by Photoshop and was calculated as root area $\times 100 \% /$ root area + substrate area (Guo et al., 2018). The bract and leaf surface area were estimated by removing all the bracts and leaves and laying them on a flat surface before photographing them from above. Using Photoshop CS 6 the bract surface area was then calculated as red area/total bract number and leaf surface area was calculated as green area/total leaf number.

Postproduction plant quality parameters. After postproduction (week 1 of 2017 for the 2016 experiment, and week 49 or week 50 in 2017), the remaining half of the plants were harvested and total leaf and bract number, number of bracts with bract edge burn (BEB), number of stems with BEB bracts, yellow leaf number, and SPAD were collected. Open and closed cyathia number per lateral branch were collected on the four main lateral branches, and open cyathia was defined as cyathia with pollen shed. Plant visual quality was rated at the end of production and postproduction from 0 (senescent plant) to 5 (healthy plant) (Starman et al., 2007) based on symptoms of open and closed cyathia abscission, red bract color fading, leaf abscission, leaf chlorosis, and BEB. In 2017 only, ethylene and photosynthetic active radiation $(P A R)$ were measured to determine differences between PM treatments. Five replications of gas samples were taken using syringes within the plant sleeve or between plant canopies with no sleeve. About $1 \mathrm{ml}$ of the gas sample was injected into a digital gas chromatograph fitted with a photoionization detector (10S plus photovac, digital gas chromatograph; SRI Instruments, Torrance, CA). PAR was measured at the top and under the plant canopy, and above the substrate surface with a quantum meter (AccuPAR PAR/Lai Ceptometer, Model LP-80; Decagon Devices, Inc., Pullman WA.).

Experimental design and statistical analysis. During greenhouse production in 2016, the experimental design was a randomized complete block design (RCBD) with four blocks on four greenhouse benches with 15 replications for a total of 240 plants. In 2017, the experimental design was RCBD with six blocks on six greenhouse benches with eight replications in each treatment for a total of 192 plants. When the interaction between two factors was significant, means were separated into each treatment combination by Student-Newman-Keuls multiple comparison at $P=0.05$. When the interaction was not significant, data were pooled by the significant factor across SMC or PM. Student's $t$ test was used to separate means at $P=0.05$ when the factor contained only two levels. At postproduction in 2016, a two-factorial experimental design (four SMC $\times$ two PM) was analyzed by a two-way ANOVA procedure. In 2017, a threefactorial experimental design (four SMC $\times$ two $\mathrm{PM} \times$ two HT) was analyzed by a splitsplit plot with PM as main plot, HT as sub plot, and SMC as sub-sub plot. When the interaction between factors was significant, means were separated into each treatment combination by Tukey's honestly significant difference at $P=0.05$. When the interaction was not significant, data were pooled by the significant factor across SMC or PM. Student's $t$ tests were used to separate means at $P=0.05$ when the factor contained only two levels. All statistical analyses were performed using SAS (Version 12; SAS Institute, Cary, NC).

Economic analysis. For the economic analysis of water usage, containers were weighed before each irrigation event during the production stage of the experiment. After irrigation, containers were allowed to drain for $1 \mathrm{~h}$ and then reweighed. The weight difference was calculated and recorded to determine total irrigation volume. Each irrigation event was documented and summed to determine total number of irrigation events during production and/or postproduction. For both tested cultivars, estimated container number per bench was calculated based on the industry standard bench size $\left(19.5^{\prime} \times\right.$ $\left.5.5^{\prime}\right)$ and the finished plant width. Space saved was based on poinsettia final width, labor saved was based on irrigation event number, irrigation amount saved was based on total irrigation amount, and fertilizer saved was calculated based on the fertilizer usage. All were calculated as the difference between the alternative irrigation method (20/40, 40/20, and 20/20) and the traditional irrigation method (40/40). Fertilizer usage was calculated based on total irrigation amount $\times 200 \mathrm{mg} \cdot \mathrm{L}^{-1} \quad 20-10-20 \quad(20 \mathrm{~N}-$ 4.4P-16.6K Peters 20-10-20; Scotts Miracle-Gro Company).

\section{Results and Discussion}

Plant morphology. 'Freedom Red' growth index (GI) differed among the four SMC beginning two weeks after their initiation until the end of production. At week 39, plants grown in VP at 40\% SMC (40/40 and $40 / 20$ ) had greater GI compared with VP at $20 \%$ SMC (20/40 and 20/20) (Fig. 1A). Starting at week 44 to the end of greenhouse production (week 47), plants grown in RP at

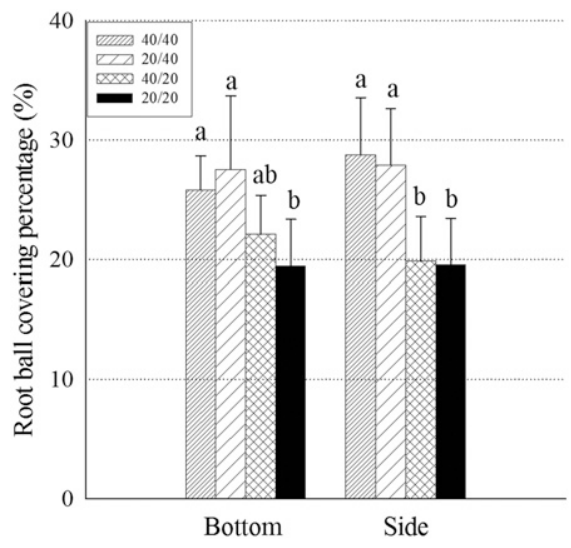

Fig. 2. Effects of four substrate moisture content (SMC) treatments (40/40, 20/40, 40/20, and 20/ $20 \% \mathrm{SMC}$ ) on root ball coverage percentage at the bottom and side of 'Freedom Red' in 2016 experiment. Means separation within the group by Student-Newman-Keuls (SNK) multiple comparisons at $P \leq 0.05$. Means with same letter are not different.

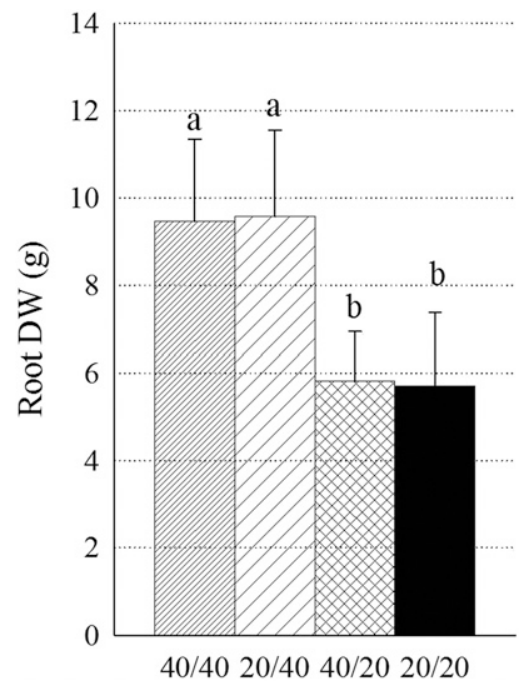

Fig. 3. Effects of four substrate moisture content (SMC) treatments $(40 / 40,20 / 40,40 / 20$, and 20/ $20 \%$ SMC) on root dry weight (DW) of 'Christmas Eve Red' in 2017 experiment. Means separation within the group by StudentNewman-Keuls (SNK) multiple comparisons at $P \leq 0.05$. Means with same letter are not different. 
$40 \%$ SMC (40/40 and 20/40) had greater GI than those grown in RP at $20 \%$ SMC (40/20 and 20/20). The final GI, at week 47 for plants grown in RP at $20 \%$ SMC $(54.5 \mathrm{~cm})$, was $14.3 \%$ lower than those grown in RP at $40 \%$ SMC (63.6 cm). Similar trends occurred with 'Christmas Eve Red'. At the end of greenhouse production, plants grown in RP at $20 \%$ SMC had $15 \%$ reduced GI $(34.9 \mathrm{~cm})$ than those grown in RP at $40 \% \mathrm{SMC}(41.1 \mathrm{~cm})$ (Fig. 1B).

'Freedom Red' plants grown in RP at $40 \%$ had greater stem length, internode length, total leaf surface area, single leaf and bract surface area, leaf thickness, and petiole thickness and shoot DW (Table 1) compared with those grown in RP at $20 \%$ SMC. At both HT (week 46 and 47) in 2017, 'Christmas Eve Red' plants grown in RP at $40 \%$ had increased stem length, bract internode length, and single bract surface area (Table 1). Increased stem length was due to increased bract internode length and not leaf internode length. The 40/20 SMC plants did not differ from the RP at $40 \%$ plants for leaf surface area (Table 1). There were no differences among SMC treatments for total leaf and bract numbers for both cultivars and no difference in open or closed cyathia per lateral branch on 'Christmas Eve Red' plants harvested week 47. At both HT, 'Christmas Eve Red' plants grown in RP at $40 \%$ had increased shoot dry weight (Table 1).

'Freedom Red' percentage of root ball coverage at the bottom of the container was the least with 20/20 SMC, while the other three SMC were not different (Fig. 2). At the side of the root ball, $20 \%$ SMC during RP had lower root ball coverage percentage compared with $40 \%$ SMC during RP (Fig. 2). Compared with 40/40, 40/20 root ball coverage was reduced on the side of the container, not at the bottom of the container, whereas the 20/20 had less root ball coverage both on the bottom and the side of the pot. This indicated water deficit reduced the root growth at the side of the container first before it was reduced at the bottom of the container. The root growth inhibition was also found with 'Christmas Eve Red' at late HT as quantified by root DW (Fig. 3).

Late stretch is a challenge for growers caused by elongation of internodes between bracts before shipping, which decreases quality and causes stem breakage during shipping. Water stressed plants have lower turgor potential, which drives the cell expansion during stem elongation; therefore, moderate water deficit ( $20 \%$ SMC) would reduce stem elongation and produce more compact plants with shorter internodes (Nemali and van Iersel, 2006). Other research also reported that $20 \%$ SMC reduced poinsettia leaf and bract surface area (Alem et al., 2015b). Leaf surface area reduction occurred in other species with applied water deficit, such as geraniums (Pelargonium zonale), mealy sage (Salvia farinacea), helichrysum (Helichrysum petiolare), English lavender (Lavandula angustifolia), geranium (Pelargonium $\times$ hortorum), and Lindheimer's beeblossom
(Gaura lindheimeri) (Andersson, 2000; Burnett and van Iersel, 2008; Caser et al., 2012; Sánchez-Blanco et al., 2009; Starman and Lombardini, 2006). Bract surface area reduction was reported as a possible result of prolonged exposure to water deficit in poinsettia 'Classical Red'- the longer the water deficit, the smaller the bract size (Alem et al., 2015 b). But this was not reported as a consistent event since the bracts surface area was unaffected by $20 \%$ SMC in another experiment conducted by the same researchers with the same cultivar (Alem et al., 2015a). Another study showed that under suddenly reduced water potential, leaf cell osmotic adjustment occurred slowly and cell wall loosening ability stayed the same, which led to significant growth inhibition. The meristem of leaves had prolonged water stress due to isolation from the xylem system combined with high evaporative demand (Hsiao and $\mathrm{Xu}, 2000$ ).

Past research reported that compared with shoot growth, the root growth was less affected by water deficit due to different cellular level responses. Compared with leaf cells, when water potential was suddenly reduced, root cell osmotic adjustment happened rapidly to recover turgor pressure and water potential, cell wall loosening ability increased, and the isolation from mature
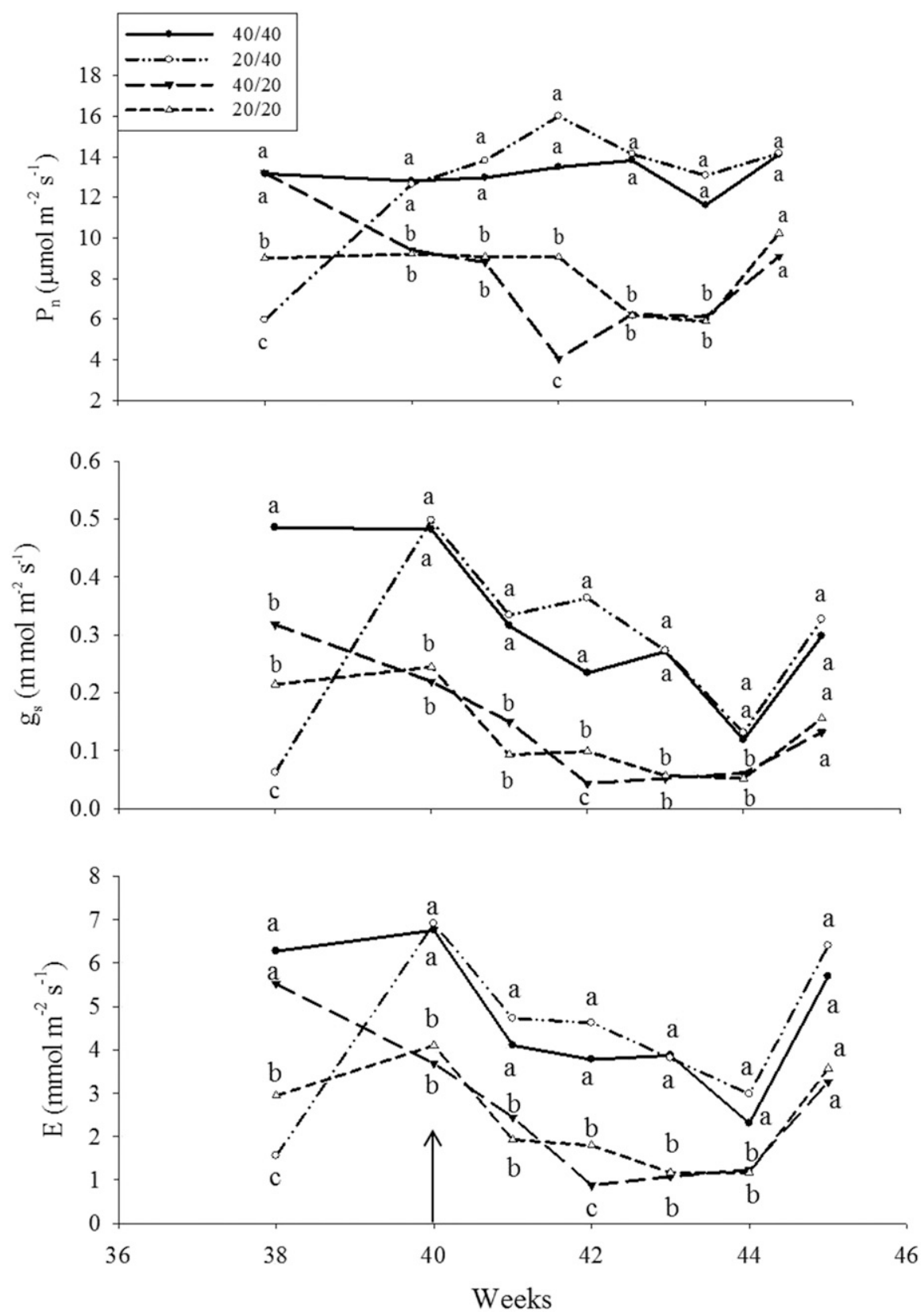

Fig. 4. Effects of four substrate moisture content (SMC) treatments $(40 / 40,20 / 40,40 / 20$, and 20/20\% SMC) on weekly leaf net photosynthesis $(\mathrm{Pn})$, stomatal conductance $\left(g_{\mathrm{S}}\right)$, and transpiration (E) of 'Christmas Eve Red' during greenhouse production week 38 to week 47 in 2017 experiment. Means separation by Student-Newman-Keuls (SNK) multiple comparisons at $P \leq 0.05$. Means with same letter are not different. The arrow denotes week 40 as the start of short day photoperiod and when SMC treatments were interchanged. 
vascular system allowed root meristem to keep growing (Hsiao and $\mathrm{Xu}, 2000$ ). Pine tree saplings (Pinus nigra L.) modified their root system architecture by producing new lateral meristems above the fine root tip, which never recovered from the water stress (Chiatante et al., 1999). Increased endogenous abscisic acid (ABA) induced by water deficit could increase root to shoot ratio and support primary root growth by suppressing ethylene production (Saab et al., 1990; Taiz et al., 2015). Reduction of root DW under water deficit environments was reported in other species such as rose (Rosa $\times$ hybrid), impatiens (Impatiens walleriana), and geranium (Pelargonium hortorum) (Cai et al., 2012; Chyliński et al., 2007).

Photosynthesis, $g_{S}$, transpiration, and water potential. In 'Christmas Eve Red', $\mathrm{P}_{\mathrm{n}}$, and $\mathrm{E}$ were higher at $40 \%$ SMC during VP (Fig. 4). After treatment interchange at the start of short days (week 40), $\mathrm{P}_{\mathrm{n}}, g_{\mathrm{S}}$, and E on 20/40 compared with $40 / 20$ was higher. From week 40 to week 44 (before the third bract transitioned to red), $40 \%$ SMC during RP had higher $\mathrm{P}_{\mathrm{n}}, g_{\mathrm{S}}$, and $\mathrm{E}$ compared with those in $20 \%$ SMC during RP. After the third fully expanded bract transitioned to red in week 45 , the $\mathrm{P}_{\mathrm{n}}, g_{\mathrm{S}}$, and $\mathrm{E}$ were taken on the first nonred leaf and were not different between SMC treatments.

Reductions on $\mathrm{P}_{\mathrm{n}}, g_{\mathrm{S}}$, and $\mathrm{E}$ under a water deficit environment were reported on poinsettia (Euphorbia pulcherrima Wild. 'Lilo'), crimson bottlebrush (Callistemon citrinus), hibiscus (Hibiscus acetosella), dusty miller (Cineraria maritima), ornamental pepper (Capsicum annuum), vinca (Catharanthus roseus), Big Bend bluebonnet (Lupinus havardii) and oleander (Nerium oleander L.) (Álvarez et al., 2011; Bayer et al., 2013; Niu et al., 2006, 2007, 2008; Nowak, 2002). In most studies, the reduction in photosynthesis rate was accompanied by inhibition of growth rate, manifested in reduced dry weight and final plant height.

Midday water potential was unaffected by SMC treatments in 'Christmas Eve Red' with the exception of week 40 (start of short days and when SMC was interchanged), and predawn water potential was unaffected by the SMC treatments. Midday water potential was reduced in week 40 with $40 / 20$ and was $61.3 \%$ lower than other SMC treatments (Fig. 5). This indicated an acclimation of plants to the water deficit environment shortly after exposure to the stress. Such acclimation was defined as morphological and physiological change in plants to compensate for the water deficit and is termed phenotypic plasticity (Debat and David, 2001). A similar acclimation was reported in angelonia (Angelonia angustifolia) (Jacobson et al., 2015).

Visual quality. During bract development of 'Freedom Red', the bract coloring percentage differed among SMC treatments during week 44 and 45 , but by week 46 all SMC treatments had the same bract coloring percentage (Figs. 6A and 7). During week 44, 'Freedom Red' plants grown in RP with 20\%

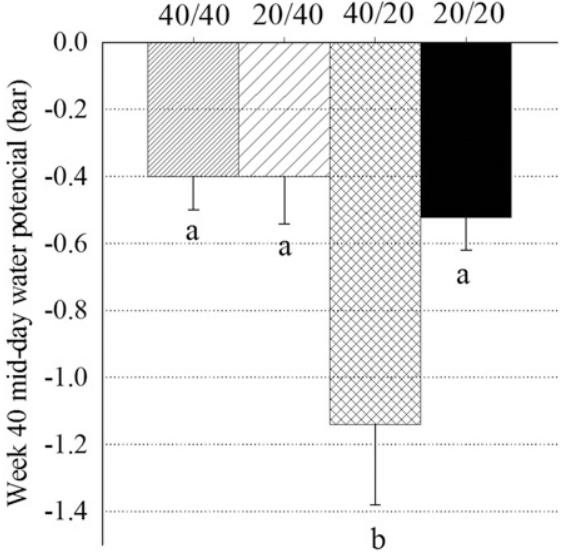

Fig. 5. Effects of four substrate moisture content (SMC) treatments $(40 / 40,20 / 40,40 / 20$, and $20 /$ $20 \%$ SMC) on midday water potential of 'Christmas Eve Red' at production week 40 at the start of short day photoperiod and when SMC treatments were interchanged in 2017 experiment. Means separation within the group by Student-Newman-Keuls (SNK) multiple comparisons at $P \leq 0.05$. Means with same letter are not different.
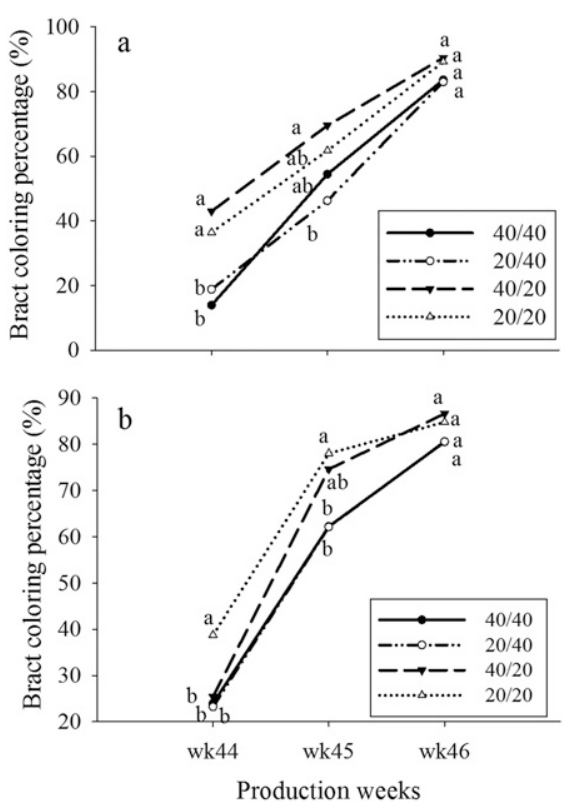

Fig. 6. Effects of four substrate moisture content (SMC) treatments $(40 / 40,20 / 40,40 / 20$, and 20 $20 \%$ SMC) on bracts coloring percentage measured over three production weeks for 'Freedom Red' in 2016 experiment (A) and 'Christmas Eve Red' in 2017 experiment (B). Means separation by Student-Newman-Keuls (SNK) multiple comparisons at $P \leq 0.05$. Means with same letter are not different. The lines of 40/40 and 20/40 are overlapping in the graph.

SMC had $23.3 \%$ greater bract coloring percentage compared with those grown in RP with $40 \%$ SMC (Fig. 6A). In week 45, 40/20 had the highest bract coloring percentage of $69.5 \%$, followed by $20 / 20$ with $61.7 \%$. By week 46 , the bract coloring percentage was not different between SMC treatments, with

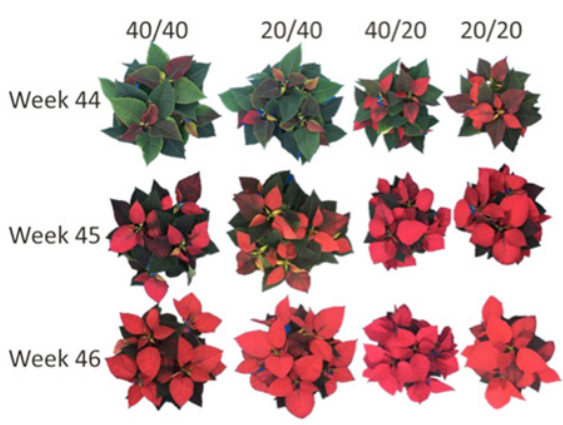

Fig. 7. Visual bract coloring percentage for four substrate moisture content (SMC) treatments (40/40, 20/40, 40/20, and 20/20\% SMC). Digital images taken over three production weeks for 'Freedom Red' in 2016 experiment.

Table 2. Effects of four substrate moisture content (SMC) treatments $(40 / 40,20 / 40,40 / 20$, and $20 /$ $20 \%$ SMC) on number (no.) of red bracts per lateral branch measured over two production weeks (42 and 43) for 'Christmas Eve Red' in 2017

\begin{tabular}{ccc}
\hline & \multicolumn{2}{c}{ No. of red bracts lateral branch } \\
\cline { 2 - 3 } & Wk 42 & Wk 43 \\
\hline $40 / 40$ & $0.2 \mathrm{~b}^{\mathrm{z}}$ & $0.7 \mathrm{~b}$ \\
$20 / 40$ & $0.3 \mathrm{~b}$ & $0.7 \mathrm{~b}$ \\
$20 / 20$ & $0.7 \mathrm{a}$ & $1.4 \mathrm{a}$ \\
$40 / 20$ & $0.6 \mathrm{a}$ & $1.3 \mathrm{a}$ \\
SMC & $* * *$ & $* * *$ \\
\hline
\end{tabular}

${ }^{\mathrm{z}}$ Means separation by Student-Newman-Keuls (SNK) multiple comparisons at $P \leq 0.05$. Means with same letter are not different.

$* * *$ Significant at $P \leq 0.001$.

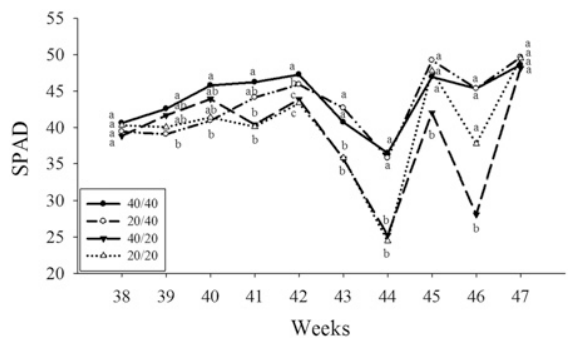

Fig. 8. Leaf chlorophyll index [Special Products Analysis Division (SPAD) values] for four substrate moisture content (SMC) treatments $(40 / 40,20 / 40,40 / 20$, and $20 / 20 \%$ SMC) of 'Freedom Red' during production week 38 to week 47 in 2016 experiment. Means separation by Student-Newman-Keuls (SNK) multiple comparisons at $P \leq 0.05$. The arrow denotes week 40 at the start of short day photoperiod and when SMC treatments were interchanged.

average of $86.5 \%$ (Fig. 6A). Similar early bract coloring was observed in 'Christmas Eve Red' (Fig. 6B). When bract coloring was first observed in weeks 42 and 43 , the number of red bracts per lateral branch was $55.6 \%$ higher in $20 \%$ SMC during RP compared with $40 \%$ SMC during RP (Table 2).

Poinsettia bract color development is achieved by accumulation of anthocyanins in vacuoles of the epidermal cells predominating over chlorophylls (Eugster and Märki-Fischer, 1991; Pomar and Barceló, 2007). Cyanidin-3-glucoside is the predominant 
Table 3. Irrigation and associated economic implications of 'Freedom Red' and 'Christmas Eve Red' in four substrate moisture content (SMC) treatments (40/40, 20/40, 40/20, and 20/20\% SMC) in 14 weeks of greenhouse production in 2016 or in 11 or 12 weeks in 2017.

\begin{tabular}{|c|c|c|c|c|c|c|c|c|}
\hline \multicolumn{9}{|c|}{2016 production wk 47 harvest } \\
\hline & $\begin{array}{c}\text { Estimated } \\
\text { pot no./bench }\end{array}$ & $\begin{array}{c}\text { Space } \\
\text { saved }(\%)\end{array}$ & $\begin{array}{l}\text { Total no.of } \\
\text { irrigation events }\end{array}$ & $\begin{array}{c}\text { Labor } \\
\text { saved }(\%)\end{array}$ & $\begin{array}{l}\text { Total irrigation } \\
\text { amount (L/pot) }\end{array}$ & $\begin{array}{l}\text { Irrigation amount } \\
\text { saved }(\%)\end{array}$ & $\begin{array}{c}\text { Fertilizer } \\
\text { usage (g/pot) }\end{array}$ & Fertilizer saved (\%) \\
\hline$\overline{40 / 40}$ & $27.0^{\mathrm{z}}$ & $0.0^{\mathrm{y}}$ & $34.0^{\mathrm{x}} \mathrm{a}^{\mathrm{w}}$ & $0.0^{\mathrm{v}}$ & $13.8^{\mathrm{u}} \mathrm{a}$ & $0.0^{\mathrm{t}}$ & $197.2^{\mathrm{s}}$ & $0.0^{\mathrm{r}}$ \\
\hline $20 / 40$ & 29.0 & 5.0 & $32.0 \mathrm{~b}$ & 5.9 & $12.9 \mathrm{~b}$ & 6.5 & 184.3 & 6.5 \\
\hline $40 / 20$ & 37.0 & 25.4 & $23.0 \mathrm{c}$ & 32.4 & $10.5 \mathrm{c}$ & 24.1 & 149.7 & 24.1 \\
\hline $20 / 20$ & 43.0 & 35.8 & $21.0 \mathrm{~d}$ & 38.2 & $10.2 \mathrm{c}$ & 26.1 & 145.7 & 26.1 \\
\hline \multicolumn{9}{|c|}{2017 production wk 46 early harvest } \\
\hline & $\begin{array}{c}\text { Estimated } \\
\text { pot no./bench }\end{array}$ & $\begin{array}{c}\text { Space } \\
\text { saved (\%) }\end{array}$ & $\begin{array}{l}\text { Total no.of } \\
\text { irrigation event }\end{array}$ & $\begin{array}{c}\text { Labor } \\
\text { saved }(\%)\end{array}$ & $\begin{array}{l}\text { Total irrigation } \\
\text { amount (L/pot) }\end{array}$ & $\begin{array}{c}\text { Irrigation amount } \\
\text { saved }(\%)\end{array}$ & $\begin{array}{c}\text { Fertilizer } \\
\text { usage }(\mathrm{g} / \mathrm{pot})\end{array}$ & Fertilizer saved (\%) \\
\hline$\overline{40 / 40}$ & 54.0 & 0.0 & $20.0 \mathrm{a}$ & 0.0 & $6.8 \mathrm{a}$ & 0.0 & 96.8 & 0.0 \\
\hline $20 / 40$ & 63.0 & 15.1 & $18.0 \mathrm{~b}$ & 10.0 & $5.4 \mathrm{~b}$ & 20.8 & 76.6 & 20.8 \\
\hline $40 / 20$ & 73.0 & 26.6 & $12.0 \mathrm{c}$ & 40.0 & $3.7 \mathrm{c}$ & 44.7 & 53.6 & 44.7 \\
\hline $20 / 20$ & 79.0 & 32.0 & $10.0 \mathrm{~d}$ & 50.0 & $3.5 \mathrm{c}$ & 48.1 & 50.3 & 48.1 \\
\hline \multicolumn{9}{|c|}{2017 production wk 47 late harvest } \\
\hline & $\begin{array}{c}\text { Estimated } \\
\text { pot no./bench }\end{array}$ & $\begin{array}{c}\text { Space } \\
\text { saved }(\%)\end{array}$ & $\begin{array}{c}\text { Total no.of } \\
\text { irrigation event }\end{array}$ & $\begin{array}{c}\text { Labor } \\
\text { saved }(\%)\end{array}$ & $\begin{array}{l}\text { Total irrigation } \\
\text { amount (L/pot) }\end{array}$ & $\begin{array}{c}\text { Irrigation amount } \\
\text { saved }(\%)\end{array}$ & $\begin{array}{c}\text { Fertilizer } \\
\text { usage }(\mathrm{g} / \mathrm{pot})\end{array}$ & Fertilizer saved $(\%)$ \\
\hline$\overline{40 / 40}$ & 54.0 & 0.0 & $23.0 \mathrm{a}$ & 0.0 & $7.5 \mathrm{a}$ & 0.0 & 106.7 & 0.0 \\
\hline $20 / 40$ & 63.0 & 15.1 & $21.0 \mathrm{~b}$ & 8.7 & $6.3 \mathrm{~b}$ & 16.2 & 89.4 & 16.2 \\
\hline $40 / 20$ & 68.0 & 20.3 & $14.0 \mathrm{c}$ & 39.1 & $4.2 \mathrm{c}$ & 44.2 & 59.6 & 44.2 \\
\hline $20 / 20$ & 73.0 & 26.0 & $12.0 \mathrm{~d}$ & 47.8 & $4.2 \mathrm{c}$ & 43.6 & 60.2 & 43.6 \\
\hline
\end{tabular}

${ }^{\mathrm{z}}$ Estimated pot number/bench was calculated as standard bench size $\left(19.5^{\prime} \times 5.5^{\prime}\right)$ /average canopy size of the plant.

${ }^{\mathrm{y}}$ Space saved is calculated based on final spacing difference between the alternative irrigation methods (20/40, 40/20, and 20/20) and the traditional irrigation method (40/40).

${ }^{\mathrm{x}}$ Total number of irrigation events during 14 weeks of production.

${ }^{\mathrm{w}}$ Means separation by Student-Newman-Keuls (SNK) multiple comparisons at $P \leq 0.05$. Means with same letter are not different

${ }^{\mathrm{v}}$ Labor saved is calculated based on irrigation event number difference between the alternative irrigation methods $(20 / 40,40 / 20$, and $20 / 20)$ and the traditional irrigation method (40/40).

${ }^{\mathrm{u}}$ Total irrigation amount per pot was the sum of each irrigation water input during 14 weeks of greenhouse production.

${ }^{t}$ Irrigation amount saved is calculated based on total irrigation amount difference between the alternative irrigation methods (20/40, 40/20, and 20/20) and the traditional irrigation method (40/40).

${ }^{\mathrm{s}}$ Fertilizer usage is calculated based on total irrigation amount $\times 200 \mathrm{mg} \cdot \mathrm{L}^{-1} 20-10-20$ (20N-4.4P-16.6K Peters 20-10-20; Scotts Miracle-Gro Company, Marysville, $\mathrm{OH})$

${ }^{\mathrm{r}}$ Fertilizer saved is calculated based on the fertilizer usage difference between the alternative irrigation methods (20/40, 40/20, and 20/20) and the traditional irrigation method (40/40).

anthocyanin causing the red color in poinsettia bracts (Gould, 2004; Slatnar et al., 2013). Under water deficit, ABA would be sent from root to shoot as a drought-sensed signal (Wan et al., 2009; Xu et al., 2010). In leaves, increased ABA concentration level not only regulated stomata conductivity (Taiz et al., 2015; Wan et al., 2009), but it potentially played an important role for upregulated miRNA156. This produced a greater level of anthocyanin gene expression, thus increased the anthocyanin concentration in vacuoles (González-Villagra et al., 2017). Plants upregulating anthocyanin synthesis during water deficit is reported in other species as well, for anthocyanin has diverse protective roles in leaves, such as to protect leaves from photoinhibition (caused by high light intensity or stomata closure during drought stress) and scavenging free radicals caused by drought stress (singlet oxygen, superoxide, hydroxyl and hydrogen peroxide) (Gould, 2004; Xu et al., 2010).

In 'Freedom Red', SPAD readings were higher at 40\% SMC treatment during VP until start of RP (week 40). One week after SMC treatments were interchanged, SPAD readings on 20/40 increased (Fig. 8). By week 44, 20\% SMC during RP had lower SPAD readings due to bract transitioning from green to red. Week 47 , the SPAD readings were taken on the first nonred leaf and were not different between SMC treatments.
SPAD readings could be increased with nitrogen concentration, chlorophyll level, fresh leaf thickness, or the water status of the leaf (Basyouni et al., 2015; Dole and Wilkins, 1999; Martínez and Guiamet, 2004). A study conducted by Niu et al. (2007) on Big Bend bluebonnet (Lupinus havardii) reported lower SPAD readings with water deficit plants. Poinsettias leaf SPAD readings were increased by a higher level of nitrogen application (Basyouni et al., 2015). Thus, the higher SPAD readings in $40 \%$ SMC found with 'Freedom Red' could be caused by the increased leaf nitrogen concentration, which would be due to the higher irrigation frequency in $40 \% \mathrm{SMC}$, combined with increased leaf thickness (Table 1).

Production irrigation and associated economic implications. Compared with the $40 / 40$ treatment, plants grown with $20 \%$ SMC during production $(20 / 40,40 / 20$, and $20 / 20$ ) had a smaller canopy, thus they required less bench space (Table 3), which potentially translates to lower overhead cost associated with bench space.

Poinsettias require fertilization with each irrigation event; reducing irrigation frequency not only reduced the total amount of irrigation water applied (as well as the amount of irrigation-associated labor), it also reduced the fertilizer usage. Compared with the 40/40 treatment, the other treatments saved irrigationrelated labor, amount of irrigation water applied, and fertilizer usage (Table 3).
Table 4. Effect of four substrate moisture content (SMC) treatments $(40 / 40,20 / 40,40 / 20$, and 20/ $20 \%$ ) and two packaging methods (PM) (no sleeve or plastic sleeve) on total bract number (no.) at the end of postproduction (week 1, 2017) for 'Freedom Red' in 2016.

\begin{tabular}{lc}
\hline & Total bract no. \\
\hline $40 / 40$ & $28.6 \mathrm{~b}^{\mathrm{z}}$ \\
$20 / 40$ & $34.6 \mathrm{a}$ \\
$40 / 20$ & $35.4 \mathrm{a}$ \\
$20 / 20$ & $38.1 \mathrm{a}$ \\
SMC & $*$ \\
PM & NS \\
SMC $\times$ PM & NS
\end{tabular}

${ }^{\mathrm{z}}$ Means separation by Tukey's honestly significant difference at $P \leq 0.05$. Means with same letter are not different.

Ns, *Nonsignificant or significant at $P \leq 0.05$, respectively.

Table 5. Effect of four substrate moisture content (SMC) treatments (40/40, 20/40, 40/20, and 20/ $20 \%$ ) and two packaging methods (PM) [no sleeve (NS) or plastic sleeve (PS)] on total leaf number (no.) and SPAD at the end of postproduction (week 1, 2017) for 'Freedom Red' in 2016.

\begin{tabular}{lcc}
\hline & Total leaf no. & SPAD \\
\hline NS & $46.2 \mathrm{a}^{\mathrm{z}}$ & $51.8 \mathrm{a}$ \\
$\mathrm{PS}$ & $37.2 \mathrm{~b}$ & $47.5 \mathrm{~b}$ \\
$\mathrm{SMC}$ & $\mathrm{NS}^{\mathrm{y}}$ & NS \\
$\mathrm{PM}$ & $*$ & $* * *$ \\
$\mathrm{SMC} \times \mathrm{PM}$ & $\mathrm{NS}$ & $\mathrm{NS}$ \\
\hline
\end{tabular}

${ }^{\mathrm{z}}$ Means separation by Student's $t$ test multiple comparisons at $P \leq 0.05$. Means with same letter are not different.

Ns, *,***Nonsignificant or significant at $P \leq 0.05$ or 0.001 , respectively. 
In the 2017 experiment, the greenhouse production stage exhibited higher savings in bench space used, irrigation-associated labor, and fertilizer usage because the "Christmas Eve Red' crop began as smaller rooted cuttings combined with two weeks shorter production time, compared with 'Freedom Red' in 2016. In 2017, in early HT, at the end of 11 weeks of greenhouse production, the $20 / 40,40 / 20$, and 20/20 treatments saved $15.1 \%, 26.6 \%$, and $32 \%$ space, respectively; $10 \%, 40 \%$, and $50 \%$ savings in irrigationrelated labor, respectively; and $20.8 \%$, $44.7 \%$, and $48.1 \%$ savings in fertilizer usage, respectively, compared with the traditional irrigation 40/40 (Table 3 ). In the late harvest, at the end of 12 weeks of greenhouse production, the 20/40, 40/20, and 20/20 treatments had similar savings (Table 3 ).

Postproduction. At the end of greenhouse production in 2016, all 'Freedom Red' plants had 66 total green leaves, 43 red bracts, a SPAD reading of 49,10 cyathia per lateral branch, and a visual quality rating of 5.0 regardless of SMC treatments. At the end of 5 weeks of postproduction (week 1, 2017), there were no differences between SMC or PM for visual rating (2.3), number of bracts with BEB (6.1), or number of stems with BEB bracts (2.1). Total bract number at end of postproduction was affected by SMC, with 40/40 abscising 15 bracts compared with the other SMC treatments, which abscised 7 bracts (Table 4). Total leaf number and SPAD were reduced by PM when plants were sleeved (Table 5). At the end of postproduction, PS packaged plants had abscised 29 total leaves, with a SPAD reading of 47.5 compared with NS packaged plants, which abscised 20 leaves and had increased SPAD over that from the beginning of postharvest (Table 5).

At the early harvest in 2017 , 'Christmas Eve Red' plants had 38.9 total green leaves, 33.5 red bracts, SPAD readings of $56.8,10$ closed cyathia and 0 open cyathia per lateral branch, and a visual quality rating of 5.0. At the late harvest, plants had 34.8 total green leaves, 43.9 red bracts, SPAD readings of $57.2,9.0$ closed cyathia and 0.5 open cyathia per lateral branch, and a visual quality rating of 5.0, regardless of SMC treatments. The differences between plants at the two HT were due to the poinsettia maturing process in which green leaves transition to red bracts and cyathia reach anthesis. In spite of these maturation processes, the overall quality of the plants was the same.

There were no $\mathrm{SMC} \times \mathrm{PM} \times \mathrm{HT}$ interactions for any measured variable at the end of two weeks of postproduction in 2017, and visual rating was unaffected by treatments, decreasing from 5.0 to 2.8. There was an interaction between SMC and PM for open cyathia number per lateral branch and number of bracts with BEB (Table 6). The 20/20 with either PM had the same amount of open cyathia per lateral branch as 40/40 with NS packaging. Plants grown with 40/40 SMC and PS packaging during postharvest abscised more cyathia than other treatments.

Table 6. Effect of four substrate moisture content (SMC) treatments (40/40, 20/40, 40/20, and 20/20\%) and two packaging methods (PM) [no sleeve (NS) or plastic sleeve (PS)] on open cyathia number (no.) per lateral branch and no. of bracts with bract edge burn (BEB) measured at the end of postproduction for 'Christmas Eve Red' in 2017.

\begin{tabular}{llcc}
\hline SMC & PM & Open cyathia no. per lateral branch & No. of bracts with BEB \\
\hline $40 / 40$ & NS & $1.9 \mathrm{a}^{z}$ & $4.3 \mathrm{a}$ \\
$40 / 40$ & PS & $0.8 \mathrm{~b}$ & $1.3 \mathrm{~b}$ \\
$20 / 40$ & NS & $0.9 \mathrm{ab}$ & $0.6 \mathrm{~b}$ \\
$20 / 40$ & PS & $1.6 \mathrm{ab}$ & $1.3 \mathrm{~b}$ \\
$40 / 20$ & NS & $1.4 \mathrm{ab}$ & $0.9 \mathrm{~b}$ \\
$40 / 20$ & PS & $1.8 \mathrm{ab}$ & $1.2 \mathrm{~b}$ \\
$20 / 20$ & NS & $2.0 \mathrm{a}$ & $0.6 \mathrm{~b}$ \\
$20 / 20$ & PS & $1.9 \mathrm{a}$ & $0.8 \mathrm{~b}$ \\
\hline
\end{tabular}

${ }^{\mathrm{z}}$ Means separation by Tukey's honestly significant difference at $P \leq 0.05$. Means with same letter are not different.

Table 7. Effect of four substrate moisture content (SMC) treatments (40/40, 20/40, 40/20, and 20/20\%) on closed cyathia number (no.) per lateral branch, and no. of stem with BEB bracts measured at the end of postproduction for 'Christmas Eve Red' in 2017.

\begin{tabular}{lcc}
\hline SMC & Closed cyathia no. per lateral branch & No. of stem with BEB bracts \\
\hline $40 / 40$ & $5.3 \mathrm{a}^{\mathrm{z}}$ & $1.6 \mathrm{a}$ \\
$20 / 40$ & $4.9 \mathrm{a}$ & $0.9 \mathrm{ab}$ \\
$40 / 20$ & $3.6 \mathrm{~b}$ & $0.6 \mathrm{~b}$ \\
$20 / 20$ & $3.6 \mathrm{~b}$ & $0.5 \mathrm{~b}$ \\
\hline
\end{tabular}

${ }^{\mathrm{z}}$ Means separation by Tukey's honestly significant difference at $P \leq 0.05$. Means with same letter are not different.

Table 8. Effects of two harvest times (HT, early and late harvest) on open and closed cyathia number (no.) per lateral branch, SPAD, and total bract no. measured at the end of postproduction for 'Christmas Eve Red' in 2017.

\begin{tabular}{lcccc}
\hline & $\begin{array}{c}\text { Open cyathia no. } \\
\text { per lateral branch }\end{array}$ & $\begin{array}{c}\text { Closed cyathia no. } \\
\text { per lateral branch }\end{array}$ & SPAD & Total bract no. \\
\hline Early & $0.6 \mathrm{~b}^{\mathrm{z}}$ & $4.0 \mathrm{~b}$ & $51.2 \mathrm{~b}$ & $31.2 \mathrm{~b}$ \\
Late & $2.5 \mathrm{a}$ & $4.7 \mathrm{a}$ & $54.0 \mathrm{a}$ & $38.2 \mathrm{a}$ \\
\hline
\end{tabular}

${ }^{\mathrm{z}}$ Means separation by Student's $t$ test multiple comparisons at $P \leq 0.05$. Means with same letter are not different.

Plants grown in 40/40 with NS packaging had $77.0 \%$ higher number of bracts with $\mathrm{BEB}$ compared with other SMC/PM combinations (Table 7). Closed cyathia abscission was affected by SMC and $40 \%$ SMC during RP lost 4.4 closed cyathia per lateral branch compared with $20 \%$ SMC during RP which lost 5.9 closed cyathia per lateral branch (Table 7). Plants grown in 40/40 had a greater number of stems with BEB bracts compared with those grown in $20 \%$ SMC during RP (Table 7). The two experiment postproduction results indicated although $20 \%$ SMC during RP abscised more closed cyathia per lateral branch during postproduction, visual quality was the same as $40 \%$ SMC during RP with more bracts and a smaller number of bracts and stems with BEB.

The 40/40 with NS packaging had reduced postproduction quality due to the high number of bracts with BEB. Bract necrosis was related to high fertilizer level, calcium $\left(\mathrm{Ca}^{2+}\right)$ deficiency, and low $\mathrm{Ca}: \mathrm{K}$ ratio (Harbaugh and Woltz, 1989; Nell and Barrett, 1986; Strømme et al., 1994) with $\mathrm{Ca}^{2+}$ deficiency considered to be the main cause of BEB in poinsettia (Dole and Wilkins, 1999; Woltz and Harbaugh, 1986). Low-light environment during postproduction contributed to poor $\mathrm{Ca}^{2+}$ uptake while stress or wounded tissues increased susceptibility to Botrytis cinerea infection which led to BEB develop-
Table 9. Effect of two packaging methods (PM) [no sleeve (NS) or plastic sleeve (PS)] on SPAD and yellow leaf number (no.) at the end of postproduction for 'Christmas Eve Red' in 2017.

\begin{tabular}{lcc}
\hline PM & SPAD & Yellow leaf no. \\
\hline NS & $54.8 \mathrm{a}^{z}$ & $3.8 \mathrm{~b}$ \\
PS & $50.3 \mathrm{~b}$ & $7.1 \mathrm{a}$ \\
\hline
\end{tabular}

${ }^{\mathrm{z}}$ Means separation by Student's $t$ test multiple comparisons at $P \leq 0.05$.

ment (Ranch, 2011). During postproduction, 40/40 with NS had the greatest irrigation demand, indicating that, compared with other treatments, 40/40 with NS was more frequently exposed to water deficit and greater postproduction leaching from RO water irrigation. Also, without a protective sleeve, plants were more exposed to bract bruising during postproduction handling. Thus, the higher bracts with BEB in 40/40 with NS could have been due to higher frequency fertilization during production, more bracts bruising during postproduction handling, and more frequent postproduction water stress, all contributing to the severity of $\mathrm{Ca}^{2+}$ deficiency.

At the end of postharvest, open and closed cyathia number per lateral branch, SPAD, and total bract number were affected by HT (Table 8). Compared with the early harvest, late harvest plants had 1.9 and 0.7 more open 
and closed cyathia per lateral branch, respectively, higher SPAD reading, and 7 more bracts (Table 8).

Harvest timing influenced poinsettia end of postproduction quality due to the different maturity levels at the time of harvest. Other

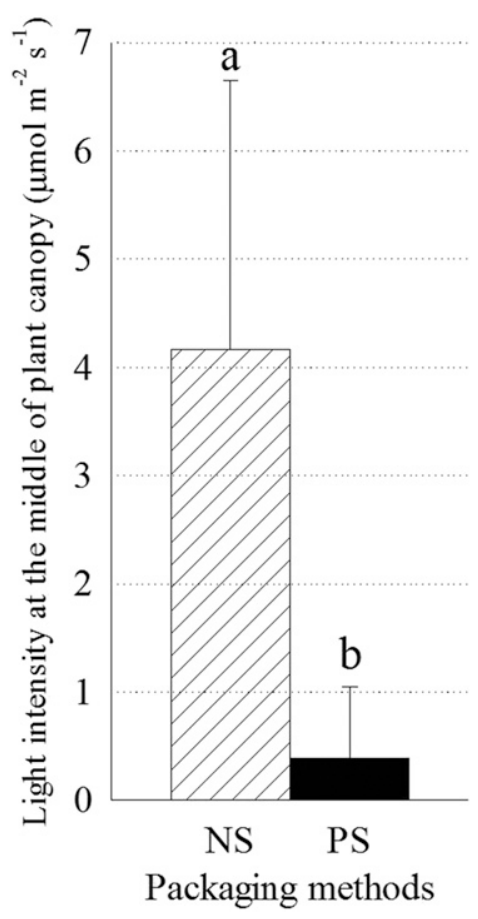

Fig. 9. Effects of two packaging methods [no sleeve (NS) and plastic sleeves (PS)] on light intensity measured at the middle of the plant canopy during week 49 for 'Christmas Eve Red' in 2017 experiment. Means separation within the group by Student- $t$ test at $P \leq 0.05$. research indicated that flower maturity level affected potted plant postproduction longevity (Plummer et al., 1990). Poinsettia harvest after pollen shed increased open and closed cyathia retention, SPAD reading, bract and leaf + bract number after two weeks of postproduction. Even though the early harvest plants had some cyathia open during postproduction, overall, the late harvest plants had better cyathia retention, and thus increased poinsettia postproduction quality.

SPAD and yellow leaf number were affected by PM (Table 9). Compared with NS packaging, PS packaging reduced SPAD and had four more yellow leaves (Table 9). PS packaging reduced light intensity by $90.6 \%$ at the middle of the plant canopy, compared with NS packaging (Fig. 9), even though light intensity was the same at the top of the canopy $\left(13.3 \mu \mathrm{mol} \cdot \mathrm{m}^{-2} \cdot \mathrm{s}^{-1}\right)$ and at the substrate surface $\left(1.2 \mu \mathrm{mol} \cdot \mathrm{m}^{-2} \cdot \mathrm{s}^{-1}\right)$. The perforated sleeves did not cause a build-up of ethylene. Measurements for ethylene were $302.0 \mathrm{ppb}$ for sleeved and nonsleeved plants.

The light intensity and ethylene concentration measurements indicated that PS reduced SPAD and increased yellow leaf number due to the light deficiency in the middle of the canopy, not ethylene concentration. Irregular irrigation, low light intensity, warm temperature, and low relative humidity caused poinsettia postproduction leaf drop from the abscission layer at the junction of petiole and the stem (Islam and Joyce, 2015). In our research, the darkinduced leaf senescence could be the major cause of lower total leaf number and SPAD reading and a higher yellow leaf number in plants with PS packaging during postproduction. Dark-induced senescence was consid- ered to have two coexisted mechanisms: light-signaling pathway or carbon starvation. Under a prolonged darkness environment, without the Pfr phytochrome to inhibit the signaling pathway, the ethylene and $\mathrm{ABA}$ signaling started, which led to leaf yellowing and senescence. Also, lack of photosynthesis under prolonged darkness led to energy deprivation-carbon starvation, which promoted catabolic process, could also contribute to dark-induced senescence (Dietrich et al., 2011; Liebsch and Keech, 2016). Leaves that are not exposed to the light catabolize and become an energy source to support cyathia retention.

Postproduction irrigation and associated economic implications. The 'Freedom Red' postproduction irrigation was unaffected by any treatment in 2016, with an average of 4.4 irrigation events, and $1.3 \mathrm{~L}$ per pot. During postproduction of 'Christmas Eve Red', the amount of irrigation water applied was reported as $\mathrm{ml} /$ pot since the volume is much lower than the volume used during the production stage. There were no interactions between SMC treatments and PM during postproduction for total irrigation events and total irrigation amount. At the end of early postproduction (week 47-48), the PS packaging saved $46.7 \%$ in retail display space and saved $20 \%$ in watering labor and irrigation water volume applied compared with the NS packaging. Watering using the $20 / 40,40 / 20$, and $20 / 20$ methods saved $15.1 \%, 26.6 \%$, and $32 \%$ in retail display space, respectively; $6.3 \%, 42.1 \%$, and $30.9 \%$ irrigation-related labor and irrigation water usage, respectively, compared with the $40 / 40$ method (Table 10). At the end of late harvest postproduction (week 48-49), PS

Table 10. Irrigation and associated economic implications for 'Christmas Eve Red' of four substrate moisture content treatments (40/40, 20/20, 40/20, and 20/40\% SMC) and two packaging methods [(no sleeve (NS) or plastic sleeve (PS)] in two weeks of early and late harvest postproduction in simulated retail environment.

\begin{tabular}{|c|c|c|c|c|c|c|}
\hline \multicolumn{7}{|c|}{2017 Postproduction wk 49 early harvest } \\
\hline Trt & $\begin{array}{c}\text { Avg bench } \\
\text { size needed }\left(\mathrm{m}^{2}\right)\end{array}$ & Space saved $(\%)$ & $\begin{array}{c}\text { Total no.of } \\
\text { irrigation events }\end{array}$ & Labor saved (\%) & $\begin{array}{c}\text { Total irrigation } \\
\text { amount (mL/pot) }\end{array}$ & $\begin{array}{c}\text { Irrigation } \\
\text { amount saved (\%) }\end{array}$ \\
\hline$\overline{\mathrm{NS}}$ & 0.2 & $0.0^{\mathrm{z}}$ & $1.1^{\mathrm{y}} \mathrm{a}^{\mathrm{x}}$ & $0.0^{\mathrm{v}}$ & $346.9^{\mathrm{u}} \mathrm{a}$ & $0.0^{\mathrm{t}}$ \\
\hline $20 / 40$ & 0.2 & 15.1 & $1.2 \mathrm{a}$ & 6.3 & $356.3 \mathrm{a}$ & 6.3 \\
\hline $40 / 20$ & 0.1 & 26.6 & $0.7 \mathrm{~b}$ & 42.1 & $220.0 \mathrm{~b}$ & 42.1 \\
\hline $20 / 20$ & 0.1 & 32.0 & $0.9 \mathrm{~b}$ & 30.9 & $262.5 \mathrm{~b}$ & 30.9 \\
\hline
\end{tabular}

2017 Postproduction wk 50 late harvest

\begin{tabular}{|c|c|c|c|c|c|c|}
\hline Trt & $\begin{array}{c}\text { Avg bench } \\
\text { size needed }\left(\mathrm{m}^{2}\right)\end{array}$ & Space saved (\%) & $\begin{array}{c}\text { Total no.of } \\
\text { irrigation events }\end{array}$ & Labor saved (\%) & $\begin{array}{c}\text { Total irrigation } \\
\text { amount (mL/pot) }\end{array}$ & $\begin{array}{c}\text { Irrigation } \\
\text { amount saved }(\%)\end{array}$ \\
\hline$\overline{\mathrm{NS}}$ & 0.2 & 0.0 & $1.1 \mathrm{a}$ & 0.0 & $333.3 \mathrm{a}$ & 0.0 \\
\hline PS & 0.1 & 48.7 & $0.5 \mathrm{~b}$ & 51.5 & $161.5 \mathrm{~b}$ & 51.5 \\
\hline $40 / 40$ & 0.2 & 0.0 & $1.1 \mathrm{a}$ & 0.0 & $337.5 \mathrm{a}$ & 0.0 \\
\hline $20 / 40$ & 0.2 & 15.1 & $1.4 \mathrm{a}$ & -27.0 & $428.6 \mathrm{a}$ & -27.0 \\
\hline $40 / 20$ & 0.1 & 20.3 & $0.5 \mathrm{~b}$ & 55.6 & $150.0 \mathrm{~b}$ & 55.6 \\
\hline $20 / 20$ & 0.1 & 26.0 & $0.5 \mathrm{~b}$ & 55.6 & $150.0 \mathrm{~b}$ & 55.6 \\
\hline
\end{tabular}

${ }^{\mathrm{z}}$ Space saved is calculated based on final spacing difference between the alternative irrigation methods (20/40, 40/20, and 20/20) and the traditional irrigation method (40/40).

${ }^{\mathrm{y}}$ Total number of irrigation events during 14 weeks of production.

${ }^{x}$ Means separation by Student's $t$ test at $P \leq 0.5$. Means with same letter are not different.

${ }^{\mathrm{w}}$ Means separation by Student-Newman-Keuls (SNK) multiple comparisons at $P \leq 0.05$. Means with same letter are not different

${ }^{\mathrm{v}}$ Labor saved is calculated based on difference in number of irrigation events between the alternative irrigation methods (20/40, 40/20, and 20/20) and the traditional irrigation method (40/40).

${ }^{\mathrm{u}}$ Total irrigation amount per pot was the sum of each irrigation water input during 14 weeks of greenhouse production.

${ }^{\mathrm{t}}$ Irrigation amount saved is calculated based on total irrigation amount difference between the alternative irrigation methods (20/40, 40/20, and $\left.20 / 20\right)$ and the traditional irrigation method (40/40). 
saved $48.7 \%$ in display space and $54.5 \%$ in labor and irrigation amount compared with NS. The 20/40, 40/20, and 20/20 watering methods saved $15.1 \%, 20.3 \%$, and $26 \%$ in retail display space needed, and $-27 \%$, $55.6 \%$, and $55.6 \%$ in irrigation-related labor and irrigation usage, respectively, compared with the 40/40 method (Table 10).

These results show that costs of production are ultimately reduced by using the alternative irrigation methods compared with the traditional 40/40 method. The reductions in costs resulted from the reduced bench space required (which reduced the residency costs expressed by overhead cost per square foot per week), the reduction in the amount (and associated costs) of water and fertilizer applied, and the reduction in irrigationassociated labor (e.g., checking emitters, etc.).

\section{Conclusion}

In our research, reducing SMC during production of poinsettias, particularly during the reproductive development stage, was beneficial for keeping plants compact throughout production and postproduction (potentially reducing overhead costs associated with bench space requirements) and served to reduce production inputs and related costs without detrimental effects on poinsettia postproduction quality. Poinsettia showed physiological adaptation and acclimation to the water deficit environment that also reduced inputs (thereby reducing potential costs) during postproduction. Plants grown under $20 \%$ SMC during reproductive production had $20 \%$ to $30 \%$ lower irrigation requirements during postproduction and earlier bract coloring compared with $40 \%$ SMC. Earlier bract coloring would allow growers to market poinsettias in a shorter period of time which also contributes to decreased costs.

Using 20\% SMC during the reproductive development stage produced more compact plants with 19\% less bract internode length on both cultivars tested. Our results show reduced SMC in the reproductive production could help prevent late stretch and postharvest losses associated with this physiological disorder.

The alternative irrigation methods used in these experiments did not differ from the traditional irrigation methods in postharvest longevity except that lower SMC caused increased closed cyathia abscission. However, this was offset by the traditional irrigation method causing higher numbers of bracts with BEB and more bract abscission. Even though sleeving during postproduction could save shelf space and postproduction irrigation related labor, our results also show prolonged use of sleeves during postproduction caused leaf yellowing and leaf abscission; therefore this practice should be limited to shipping followed by removal during retail. 'Christmas Eve Red' plants harvested after pollen shed had better postproduction longevity than those harvested before pollen shed, another possible practice to improve postharvest quality.

In conclusion, using 20\% SMC during reproductive production produced compact poinsettias with lower postproduction irrigation requirement and higher postproduction quality.

\section{Literature Cited}

Alem, P., P.A. Thomas, and M.W. van Iersel. 2015a. Controlled water deficit as an alternative to plant growth retardants for regulation of poinsettia stem elongation. HortScience 50: $565-569$.

Alem, P., P.A. Thomas, and M.W. van Iersel. $2015 \mathrm{~b}$. Use of controlled water deficit to regulate poinsettia stem elongation. HortScience 50:234-239.

Álvarez, S., A. Navarro, E. Nicolás, and M.J. Sánchez-Blanco. 2011. Transpiration, photosynthetic responses, tissue water relations and dry mass partitioning in Callistemon plants during drought conditions. Scientia Hort. 129:306-312.

Andersson, N.E. 2000. Weight controlled irrigation of potted plants. Acta Hort. 559:371-375.

Barnes, L., B. Drees, and C. Hall. 2014. The Texas poinsettia producers guide. Texas Agr. Ext. Serv. Texas A\&M Univ. 27 June 2018. $<$ https://aggie-horticulture.tamu.edu/ornamental/ the-texas-poinsettia-producers-guide/economicsmarketing/>

Barrett, J., T. Nell, T. Blom, and P. Hammer. 1995 Poinsettia bract edge burn: Potential causes and role of calcium sprays and Botrytis. HortScience 30:771.

Basyouni, R., B.L. Dunn, and C. Goad. 2015. Use of nondestructive sensors to assess nitrogen status in potted poinsettia (Euphorbia pulcherrima L. (Willd. ex Klotzsch)) production. Scientia Hort. 192:47-53.

Bayer, A., I. Mahbub, M. Chappell, J. Ruter, and M.W. van Iersel. 2013. Water use and growth of hibiscus acetosella 'Panama Red' grown with a soil moisture sensor-controlled irrigation system. HortScience 48:980-987.

Burnett, S.E. and M.W. van Iersel. 2008. Morphology and irrigation efficiency of gaura lindheimeri grown with capacitance sensor-controlled irrigation. HortScience 43:1555-1560.

Cai, X., T. Starman, G. Niu, C. Hall, and L. Lombardini. 2012. Response of selected garden roses to drought stress. HortScience 47:1050 1055.

Cai, X., T. Starman, G. Niu, and C. Hall. 2014. The effect of substrate moisture content on growth and physiological responses of two landscape roses (Rosa hybrida L.). HortScience 49:741745.

Caser, M., B. Ruffoni, and V. Scariot. 2012. Screening for drought tolerance in Salvia spp. and Helichrysum petiolare: A way to select low maintenance ornamental plants. Acta Hort 953:240-246.

Cavins, T.J., B.E. Whipker, W.C. Fonteno, B Harden, I. McCall, and J.L. Gibson. 2000 Monitoring and managing $\mathrm{pH}$ and $\mathrm{EC}$ using the PourThru extraction method. Hort. Information Leaflet 590:1-17.

Chiatante, D., A. Di Iorio, L. Maiuro, and S.G. Scippa. 1999. Effect of water stress on root meristems in woody and herbaceous plants during the first stage of development. Plant Soil 217(1):159-172.

Chyliński, W.K., A.J. Łukaszewska, and K. Kutnik. 2007. Drought response of two bedding plants. Acta Physiol. Plant. 29(5):399-406.
Debat, V. and P. David. 2001. Mapping phenotypes: Canalization, plasticity and developmental stability. Trends Ecol. Evol. 16(10): 555-561.

Dietrich, K., F. Weltmeier, A. Ehlert, C. Weiste, M. Stahl, K. Harter, and W. Dröge-Laser. 2011. Heterodimers of the Arabidopsis transcription factors bZIP1 and bZIP53 reprogram amino acid metabolism during low energy stress. Plant Cell 23:381-395.

Dole, J.M. and H.F. Wilkins. 1999. Floriculture: Principles and species. Prentice-Hall Inc., Upper Saddle River, NJ.

Ecke, P., J.E. Faust, A. Higgins, and J. Williams. 2004. The Ecke poinsettia manual. Ball Publ., Batavia, IL.

Eugster, C.H. and E. Märki-Fischer. 1991. The chemistry of rose pigments. Angew. Chem. Intl. Ed. Engl. 30:654-672.

Fonteno, W., C. Hardin, and J. Brewster. 1995. Procedures for determining physical properties of horticultural substrates using the NCSU Porometer. Hort. Substrates Lab., N. C. State Univ., Raleigh, NC.

González-Villagra, J., L.V. Kurepin, and M.M. Reyes-Díaz. 2017. Evaluating the involvement and interaction of abscisic acid and miRNA156 in the induction of anthocyanin biosynthesis in drought-stressed plants. Planta 246(2):299 312.

Gould, K.S. 2004. Nature's Swiss army knife: The diverse protective roles of anthocyanins in leaves. J. Biomed. Biotechnol. 5:314-320.

Guo, Y., T. Starman, and C. Hall. 2018. Reducing substrate moisture content (SMC) during greenhouse production and postproduction of angelonia and heliotrope improves crop quality and economic value. HortScience 53:10061011.

Harbaugh, B. and S. Woltz. 1989. Fertilization practice and foliar-bract calcium sprays reduce incidence of marginal bract necrosis of poinsettia. HortScience 24:465-468.

Hsiao, T.C. and L.K. Xu. 2000. Sensitivity of growth of roots versus leaves to water stress: Biophysical analysis and relation to water transport. J. Expt. Bot. 51:1595-1616.

Islam, M.A. and D.C. Joyce. 2015. Postharvest behavior and keeping quality of potted poinsettia: A review. Res. Agr. Livestock and Fisheries 2(2): 185-196

Jacobson, A.B., T.W. Starman, and L. Lombardini. 2015. Substrate moisture content effects on growth and shelf life of Angelonia angustifolia. HortScience 50:272-278

Liebsch, D. and O. Keech. 2016. Dark-induced leaf senescence: New insights into a complex lightdependent regulatory pathway. New Phytol. 212(3):563-570.

Markwell, J., J.C. Osterman, and J.L. Mitchell. 1995. Calibration of the Minolta SPAD-502 leaf chlorophyll meter. Photosynth. Res. 46:467-472.

Martínez, D. and J. Guiamet. 2004. Distortion of the SPAD 502 chlorophyll meter readings by changes in irradiance and leaf water status. Agronomie 24:41-46.

Meijón, M., R. Rodríguez, M.J. Cañal, and I. Feito. 2009. Improvement of compactness and floral quality in azalea by means of application of plant growth regulators. Scientia Hort. 119(2): 169-176.

Nell, T. and J. Barrett. 1986. Growth and incidence of bract necrosis in 'Gutbier V-14 Glory' poinsettia. J. Amer. Soc. Hort. Sci. 111:266269.

Nell, T.A., R.T. Leonard, and J.E. Barrett. 1995. Production factors affect the postproduction 
performance of Poinsettia - A review. VI International Symposium on Postharvest Physiology of Ornamental Plants 405:132-137.

Nemali, K.S. and M.W. van Iersel. 2006. An automated system for controlling drought stress and irrigation in potted plants. Scientia Hort. 110:292-297.

Niu, G., D.S. Rodriguez, and W. Mackay. 2008. Growth and physiological responses to drought stress in four oleander clones. J. Amer. Soc. Hort. Sci. 133:188-196.

Niu, G., D.S. Rodriguez, L. Rodriguez, and W. Mackay. 2007. Effect of water stress on growth and flower yield of big bend bluebonnet. HortTechnology 17:557-560.

Niu, G., D.S. Rodriguez, and Y.-T. Wang. 2006. Impact of drought and temperature on growth and leaf gas exchange of six bedding plant species under greenhouse conditions. HortScience 41:1408-1411.

Nowak, J.S. 2002. Effect of different soil water potential on leaf transpiration and on stomatal conductance in poinsettia. Acta Agrobot. 55(2): 27-36.

Plummer, J.A., T.E. Welsh, and A.M. Armitage. 1990. Stages of flower development and postproduction longevity of potted Zantedeschia aethiopica 'Childsiana'. HortScience 25:675676.

Pomar, F. and A.R. Barceló. 2007. Are red leaves photosynthetically active? Biol. Plant. 51(4): 799-800.
Ranch, P.E. 2011. Poinsettia, postproduction issues. University of Florida. Gainesville. 16 June 2018. <http://hort.ifas.ufl.edu/floriculture/ poinsettia/beb.shtml $>$.

Ranch, P.E. 2012. Commercial floriculture: Poinsettia major postproduction issues. University of Florida. Gainesville. 26 Oct. 2018. <https://hort. ifas.ufl.edu/floriculture/poinsettia/postproduction. shtml $>$.

Saab, I.N., R.E. Sharp, J. Pritchard, and G.S. Voetberg. 1990. Increased endogenous abscisic acid maintains primary root growth and inhibits shoot growth of maize seedlings at low water potentials. Plant Physiol. 93(4):1329-1336.

Sánchez-Blanco, M.J., S. Álvarez, A. Navarro, and S. Bañón. 2009. Changes in leaf water relations, gas exchange, growth and flowering quality in potted geranium plants irrigated with different water regimes. J. Plant Physiol. 166:467-476.

Schuch, U., R.A. Redak, and J. Bethke. 1996 Whole-plant response of six poinsettia cultivars to three fertilizer and two irrigation regimes. J. Amer. Soc. Hort. Sci. 121:69-76.

Slatnar, A., M. Mikulic-Petkovsek, R. Veberic, F. Stampar, and V. Schmitzer. 2013. Anthocyanin and chlorophyll content during poinsettia bract development. Scientia Hort. 150:142-145.

Starman, T. and L. Lombardini. 2006. Growth, gas exchange, and chlorophyll fluorescence of four ornamental herbaceous perennials during water deficit conditions. J. Amer. Soc. Hort. Sci. 131:469-475.

Starman, T.W., S.E. Beach, and K.L. Eixmann. 2007. Postharvest decline symptoms after simulated shipping and during shelf life of 21 cultivars of vegetative annuals. HortTechnology $17: 544-551$.

Strømme, E., A. Selmer-Olsen, H. Gislerød, and R. Moe. 1994. Cultivar differences in nutrient absorption and susceptibility to bract necrosis in poinsettia (Euphorbia pulcherrima Willd. ex Klotzsch). Gartenbauwissenschaft 59(1):6-12.

Taiz, L., E. Zeiger, I.M. Møller, and A. Murphy. 2015. Plant physiology and development. Sinauer Associates, Inc., Sunderland, MA.

USDA. 2016. National Agricultural Statistics Service. 26 Apr. 2018. <http://usda.mannlib.cornell. edu/usda/current/FlorCrop/FlorCrop-04-26-2016. pdfs.

Wan, J., R. Griffiths, J. Ying, P. McCourt, and Y. Huang. 2009. Development of drought-tolerant canola (L.) through genetic modulation of ABA-mediated stomatal responses. Crop Sci. 49(5):1539-1554.

Woltz, S. and B. Harbaugh. 1986. Calcium deficiency as the basic cause of marginal bract necrosis of 'Gutbier V-14 Glory' poinsettia. HortScience 21:1403-1404.

Xu, Z., G. Zhou, and H. Shimizu. 2010. Plant responses to drought and rewatering. Plant Signal. Behav. 5(6):649-654. 